\title{
NJK14013, a novel synthetic estrogen receptor- $\alpha$ agonist, exhibits estrogen receptor-independent, tumor cell-specific cytotoxicity
}

\author{
HYE-IN KIM $^{1 *}$, TAELIM KIM ${ }^{2 *}$, JI-EUN KIM ${ }^{1}$, JUN LEE $^{2}$, JINYUK HEO $^{2}$, \\ NA-RAE LEE ${ }^{1}$, NAM-JUNG KIM ${ }^{2}$ and KYUNG-SOO INN ${ }^{1}$ \\ Departments of ${ }^{1}$ Pharmaceutical Science and ${ }^{2}$ Pharmacy, College of Pharmacy, \\ Kyung Hee University, Dongdaemun-gu, Seoul 130-701, Republic of Korea
}

Received March 5, 2015; Accepted April 16, 2015

DOI: 10.3892/ijo.2015.3002

\begin{abstract}
Estrogens act through interactions with estrogen receptors (ERs) to play diverse roles in various pathophysiological conditions. A number of synthetic selective estrogen receptor modulators (SERMs), such as tamoxifen and raloxifene, have been developed and used to treat ER-related diseases, including breast cancer and osteoporosis. Here, we identified a novel compound, bis(4-hydroxyphenyl) methanone- $O$-isopentyl oxime, designated NJK14013, as an ER agonist. NJK14013 activated ER-dependent transcription in a concentration-dependent manner, while suppressing androgen receptor-dependent transcriptional activity. It induced the activation-related phosphorylation of ER and enhanced the transcription of growth regulation by estrogen in breast cancer 1 (GREB1), further supporting its ER-stimulating activity. NJK14013 exerted anti-proliferative effects on various cancer cell lines, including an ER-negative breast cancer cell line, suggesting that it is capable of suppressing the growth of cancer cells independent of its ER-modulating activity. In addition, NJK14013 treatment resulted in significant apoptotic death of MCF7 and Ishikawa cancer cells, but did not induce apoptosis in non-cancer human umbilical vein endothelial cells. Collectively, our findings demonstrate that NJK14013 is a novel SERM that can activate ER-mediated transcription in MCF7 cells and suppress the proliferation of various cancer cells, including breast cancer cells and endometrial cancer
\end{abstract}

Correspondence to: Professor Kyung-Soo Inn, Department of Pharmaceutical Science, College of Pharmacy, Kyung Hee University, 26 Kyungheedae-ro, Dongdaemun-gu, Seoul 130-701, Republic of Korea

E-mail: innks@khu.ac.kr

Professor Nam-Jung Kim, Department of Pharmacy, College of Pharmacy, Kyung Hee University, 26 Kyungheedae-ro, Dongdaemun-gu, Seoul 130-701, Republic of Korea

E-mail: kimnj@khu.ac.kr

*Contributed equally

Key words: selective estrogen receptor modulator, estrogen, estrogen receptor, antitumor effect, NJK14013 cells. These results suggest that NJK14013 has potential as a novel SERM for anticancer or hormone-replacement therapy with reduced risk of carcinogenesis.

\section{Introduction}

Estrogens serve various physiological functions and are critical for the development and maintenance of diverse tissues, including reproductive tissues, adipose tissues, and skeletal tissues though their interactions with estrogen receptors (ERs). In turn, estrogens and their receptors have been implicated in various pathophysiologic conditions, including cancers, cognitive diseases, and postmenopausal syndrome. Accordingly, there have been numerous efforts to develop compounds capable of modulating ER-mediated signaling pathways, and several selective estrogen receptor modulators (SERMs) and aromatase inhibitors have been approved. To date, the major clinical applications of SERMs are in the treatment of ER-positive breast cancer and the prevention and treatment of postmenopausal symptoms caused by the low levels of estrogens that accompany osteoporosis (1-3). In addition, recent studies suggest the possible use of SERMs as neuroprotective agents $(4,5)$.

Anti-estrogenic ER-modulating agents such as tamoxifen and toremifene, which directly interact with ERs and suppress their function, have been commonly used to treat patients with ER-positive breast cancer (6-8). However, a majority of patients treated with tamoxifen eventually develop resistance and experience metastases $(9,10)$. Moreover, tamoxifen is known to increase the risk of thromboembolism and endometrial changes, including endometrial cancer (11-13).

On the other hand, estrogen and estrogenic compounds have been used to treat estrogen deficiency-related postmenopausal symptoms. It has been reported that $\sim 75 \%$ of perimenopausal and postmenopausal women experience various symptoms owing to estrogen withdrawal, including vasomotor menopausal syndrome (VMS) and hip, spine or wrist fracture due to osteoporosis $(1,14,15)$. Hormone replacement therapy (HRP) was once widely used to ameliorate and prevent postmenopausal symptoms, including VMS and osteoporosis. However, its use has drastically declined since a report by the Women's Health Initiative (WHI) showed that HRP increases the risk of strokes, breast cancer, and pulmonary embolism (16-19). To 
overcome these limitations, several next generation SERMs have been developed or are under development (3). For example, raloxifene, a SERM that exerts estrogenic effects on bones and anti-estrogenic effects on the uterus and breast, has been used clinically to prevent osteoporosis in postmenopausal women (2,20). Recently, another estrogenic SERM, ospemifene, was approved by the US Food and Drug Administration for dyspareunia associated with vulvar and vaginal atrophy and menopause (21). Considering the increased risks and adverse effects of using SERMs, there are still unmet needs for alternative, safer SERMs with an improved risk-benefit ratio. In an effort to identify new SERMs, we generated a chemical library composed of synthetic compounds structurally related to bisphenol $\mathrm{A}$, which is well known to exert hormone-like actions. In the present study, we identified a synthetic compound that acts as an ER-signaling agonist and characterized its anticancer effects.

\section{Materials and methods}

\section{Synthesis of NJK13054 and NJK14013}

NJK13054 [(E)-1-(4-hydroxyphenyl)ethanone-O-butyl oxime]. To a solution of 4-hydroxyacetophenone $(30 \mathrm{mg}, 0.22 \mathrm{mmol})$ in ethanol $(1 \mathrm{ml})$ was added $O$-butylhydroxylamine hydrochloride $(33 \mathrm{mg}, 0.26 \mathrm{mmol})$. The reaction mixture was stirred at ambient temperature for $4 \mathrm{~h}$, quenched with $\mathrm{H}_{2} \mathrm{O}$, and diluted with ethyl acetate (EtOAc). The combined organic layer was washed with $\mathrm{H}_{2} \mathrm{O}$, dried over $\mathrm{MgSO}_{4}$, and concentrated in vacuo. Purification of the residue via flash column chromatography on silica (EtOAc: $n$-hexane $=1: 6-1: 5)$ yielded $36 \mathrm{mg}$ of NJK13054 (79\%); ${ }^{1} \mathrm{H}-\mathrm{NMR}\left(400 \mathrm{MHz}, \mathrm{CDCl}_{3}\right) \delta 7.46(2 \mathrm{H}, \mathrm{d}$, $J=8.7 \mathrm{~Hz}), 6.71(2 \mathrm{H}, \mathrm{d}, J=8.7 \mathrm{~Hz}), 6.53(1 \mathrm{H}, \mathrm{s}), 4.17(2 \mathrm{H}, \mathrm{t}$, $J=6.6 \mathrm{~Hz}), 2.21(3 \mathrm{H}, \mathrm{s}), 1.71-1.64(2 \mathrm{H}, \mathrm{m}), 1.44-1.38(2 \mathrm{H}, \mathrm{m})$, $0.94(3 \mathrm{H}, \mathrm{t}, J=7.4 \mathrm{~Hz})$.

NJK14013 [bis(4-hydroxyphenyl)methanone-O-isopentyl oxime]. To a solution of 4,4'-dihydroxybenzophenone (50 mg, $0.23 \mathrm{mmol})$ in ethanol $(2 \mathrm{ml})$ was added $O$-isopentylhydroxylamine hydrochloride $(33 \mathrm{mg}, 0.32 \mathrm{mmol})$. The reaction mixture was stirred at $70^{\circ} \mathrm{C}$ for $6 \mathrm{~h}$, quenched with $\mathrm{H}_{2} \mathrm{O}$, and diluted with EtOAc. The combined organic layer was washed with $\mathrm{H}_{2} \mathrm{O}$, dried over $\mathrm{MgSO}_{4}$, and concentrated in vacuo. Purification of the residue via flash column chromatography on silica (EtOAc: $n$-hexane $=1: 6-1: 5$ ) yielded $36 \mathrm{mg}$ of NJK14013 (53\%); ${ }^{1} \mathrm{H}-\mathrm{NMR}\left(400 \mathrm{MHz}, \mathrm{CDCl}_{3}\right) \delta 7.31$ $(2 \mathrm{H}, \mathrm{d}, J=8.6 \mathrm{~Hz}), 7.25(2 \mathrm{H}, \mathrm{d}, J=8.6 \mathrm{~Hz}), 6.80(2 \mathrm{H}, \mathrm{d}, J=8.6 \mathrm{~Hz})$, $6.70(2 \mathrm{H}, \mathrm{d}, J=8.6 \mathrm{~Hz}), 6.00(1 \mathrm{H}, \mathrm{s}), 4.19(2 \mathrm{H}, \mathrm{t}, J=6.9 \mathrm{~Hz}), 1.65$ $(1 \mathrm{H}, \mathrm{m}, J=6.8 \mathrm{~Hz}), 1.60-1.55(2 \mathrm{H}, \mathrm{m}), 1.26(1 \mathrm{H}, \mathrm{m}), 0.89(6 \mathrm{H}, \mathrm{d}$, $J=6.5 \mathrm{~Hz}$ ).

Cells. MCF7 and MDA-MB-231 human breast cancer cell lines and the LNCaP (CRL-1740) human prostate cancer cell line were maintained in RPMI-1640 medium containing $10 \%$ fetal bovine serum (FBS) and penicillin/streptomycin (100 U/ml). The Ishikawa human endometrial adenocarcinoma cell line and A549 human lung adenocarcinoma epithelial cell line were maintained in Dulbecco's modified Eagle's medium (DMEM) containing 10\% FBS and penicillin/streptomycin (100 U/ml). Human umbilical vein endothelial cells (HUVECs; ATCC CRL-1730) were propagated in endothelial cell growth media (Lonza). For luciferase assays and reverse-transcription quantitative polymerase chain reaction (RT-qPCR) assays using 17 $\beta$-estradiol (E2) or test compounds, MCF7 cells were maintained in phenol red-free RPMI containing $10 \%$ charcoalstripped FBS for 1 day before treatment.

Luciferase assays. Stimulation of ER transcriptional activity by test compounds was assessed by dual-luciferase assays as previously described, with slight modifications (22). Briefly, MCF7 cells were co-transfected with estrogen response element (ERE)-Luc and thymidine kinase-Renilla (pRL-TK) expression plasmids and maintained in phenol-red-free RPMI containing 10\% charcoal-stripped (CS) FBS for 1 day. Cells were treated with the indicated compounds for $24 \mathrm{~h}$ and analyzed using dual-luciferase assays (Promega, Madison, WI, USA) according to the manufacturer's instructions. Activation of the androgen receptor (AR) was assessed in a similar manner by transfecting LNCaP cells with a prostate-specific antigen (PSA)-enhancer/promoter-luciferase reporter construct or mouse mammary tumor virus (MMTV) enhancer/promoterluciferase reporter plasmid together with a pRL-TK expression plasmid.

Immunoblotting. Effects of NJK14013 on the phosphorylation status of ER $\alpha$ were analyzed by immunoblotting. MCF7 cells were treated with different concentrations of NJK14013 for $24 \mathrm{~h}$. After lysing cells with RIPA buffer containing phosphatase inhibitors (Sigma-Aldrich, St. Louis, MO, USA), proteins were resolved by sodium dodecyl sulfate-polyacrylamide gel electrophoresis (SDS-PAGE) and immunoblotted using anti-phospho-ER (Cell Signaling Technology, \#8644, Beverly, MA, USA), anti-ER $\alpha$ (Cell Signaling Technology, \#8644), and anti- $\beta$-actin (Santa Cruz, sc47778, Dallas, TX, USA) antibodies. Cell proliferation was assessed by treating cells with E2 or NJK14013 for $24 \mathrm{~h}$, then lysing cells and analyzing cell lysates by immunoblotting using an anti-PCNA antibody (Santa Cruz, sc7907).

Molecular modeling of interactions between ER and NJK14013. Molecular docking studies were performed based on the human-ER $\alpha$ crystal structure (PDB code: 2QXS) using Autodock 4.2 (Molecular Graphic Laboratory) (23). Results of docking studies were visualized using Chimera 1.10 software (24).

$R N A$ preparation and $R T-q P C R$. The transcriptional activity of ER was analyzed by determining transcript levels of the ER target, growth regulation by estrogen in breast cancer 1 (GREB1), by RT-qPCR, as described previously (22). MCF7 cells were seeded and maintained in phenol-red-free RPMI containing $10 \% \mathrm{CS}$ FBS for 1 day prior to treatment with E2 or NJK14013. After incubating cells for an additional $24 \mathrm{~h}$, RNA was extracted and cDNA, used as a template for quantitative PCR, was synthesized from total RNA using Superscript III reverse transcriptase (Invitrogen, Carlsbad, CA, USA) and oligo $_{20}(\mathrm{dT})$ primers. $\beta$-actin was used as a reference gene for normalization. The following primer pairs were used for qPCR: GREB1, 5'-gtggtagccgagtggacaat-3' (sense) and 5'-aaac ccgtctgtggtacagc-3' (antisense); and $\beta$-actin, 5'-gggaaatcgt gcgtgacatt-3' (sense) and 5'-ggagttgaaggtagttt cgt-3' (antisense). 
A<smiles>CCCCO/N=C(\C)c1ccc(O)cc1</smiles><smiles>CC(C)CCON=C(c1ccc(O)cc1)c1ccc(O)cc1</smiles>

C

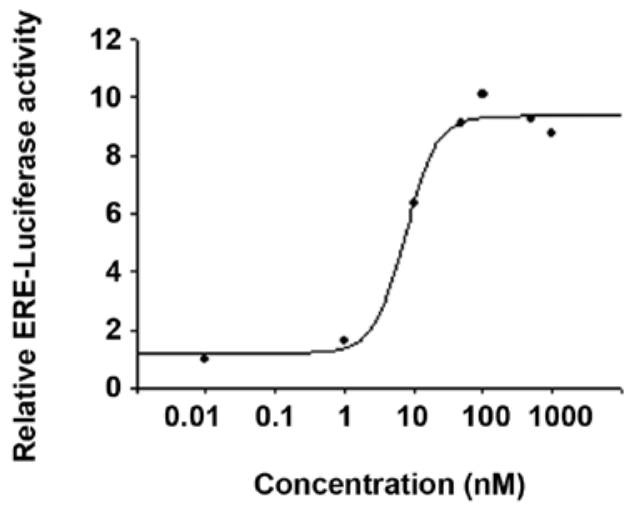

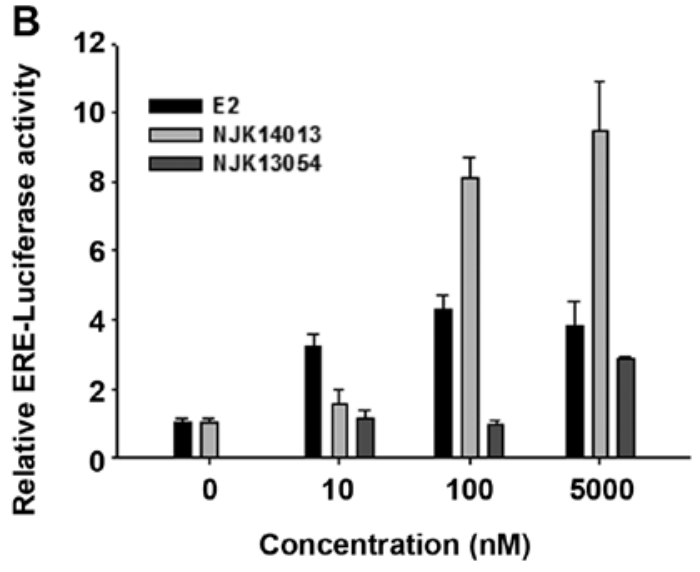

D

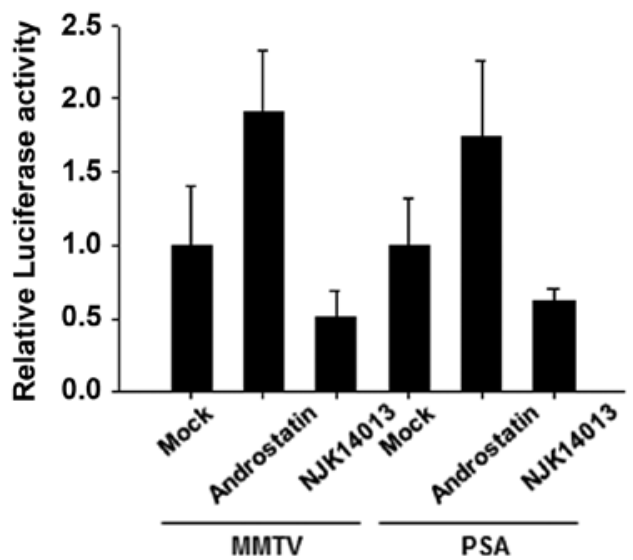

Figure 1. Identification of NJK14013 as a novel agonist of estrogen signaling. (A) Chemical structures of NJK13054 and NJK14013. (B) Agonistic activity of NJK14013 and NJK13054 on ERE-luciferase promoter activity. MCF7 cells transfected with an ERE-luciferase reporter and TK-Renilla luciferase reporter plasmids were treated with the indicated concentrations of NJK13054, NJK14013 or E2, and then subjected to dual-luciferase assays. (C) Concentrationdependent stimulation of ERE-promoter activity by NJK14013. MCF7 cells were treated with increasing concentrations of NJK14013 as in (B). EC 50 value was determined from triplicate samples. (D) Effects of NJK14013 on MMTV and PSA promoter activity. LNCaP cells were transfected with a PSA-enhancer/ promoter- or an MMTV enhancer/promoter-luciferase construct together with a TK-Renilla reporter plasmid. Cells were treated with androstain (1 $\mu \mathrm{M})$ or $\mathrm{NJK} 14013(10 \mu \mathrm{M})$ for $24 \mathrm{~h}$ and assayed for luciferase activity. Data are presented as means $\pm \mathrm{SD}$.

Cell proliferation and cell cytotoxicity assay. The effects of compounds on tumor cell growth were determined by seeding MCF7, Ishikawa, MDA-MB-232, and A549 cells $\left(1 \times 10^{4}\right.$ cells/well) onto 96-well tissue culture plates and treating with different concentrations of E2 or NJK14013 for 24,48 or $72 \mathrm{~h}$. Cell proliferation was determined using an MTT [3-(4,5-dimethylthiazol-2-yl)-2,5-diphenyltetrazolium bromide] assay. After incubation with the compound, the culture medium was replaced with fresh medium containing $20 \mu 1$ of MTT $(5 \mathrm{mg} / \mathrm{ml})$, and cells were incubated for an additional $4 \mathrm{~h}$. Thereafter, the medium was removed, and cells were lysed with dimethyl sulfoxide. The absorbance of lysates was determined at $570 \mathrm{~nm}$ using a microplate reader. The cytotoxicity of compounds toward tumor cells was analyzed by seeding Ishikawa cells and HUVEC cells $\left(4 \times 10^{4}\right.$ cells/well) onto 96-well plates and treating as indicated in the text. Cell viability was determined by MTT assays in a similar manner.

Apoptosis assay. Apoptotic cell death was assessed by Annexin V/7-AAD staining. For Annexin V assays, cells were treated with vehicle or NJK14013 $(10 \mu \mathrm{M})$ as indicated. Cells were stained with Annexin V-PE and 7-AAD using a Guava Nexin kit (Millipore, Billerica, MA, USA) and analyzed with a Guava easyCyte flow cytometer according to the manufacturer's instructions.

\section{Results}

NJK14013 is a novel synthetic ER agonist that stimulates ER transcriptional activity. With the aim of developing new ER-modulating agents, we screened an in-house synthetic library containing bisphenol-A-inspired compounds. These screens identified two compounds, NJK14013 and NJK13054, that upregulated the activity of an estrogen response element (ERE)-containing luciferase reporter construct (ERE-luciferase) in MCF7 cells (Fig. 1A and B). Notably, NJK14013 showed higher activity than E2, the endogenous ligand, at concentrations of $100 \mathrm{nM}$ and $1 \mu \mathrm{M}$, but displayed weaker activity at $10 \mathrm{nM}$ (Fig. 1B). Since the agonistic effect of NJK14013 was greater than that of NJK13054, NJK14013 was used for subsequent studies. NJK14013 induced concentrationdependent stimulation of ERE-mediated transcriptional 
A

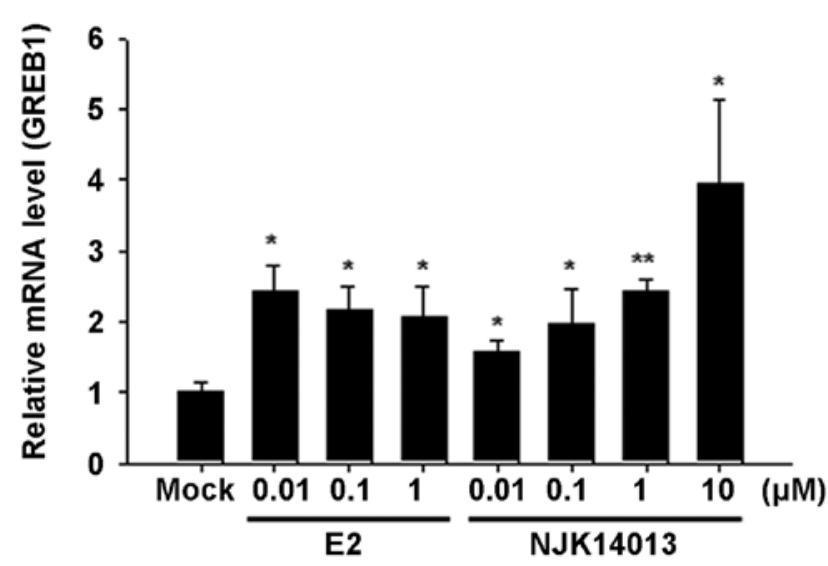

B

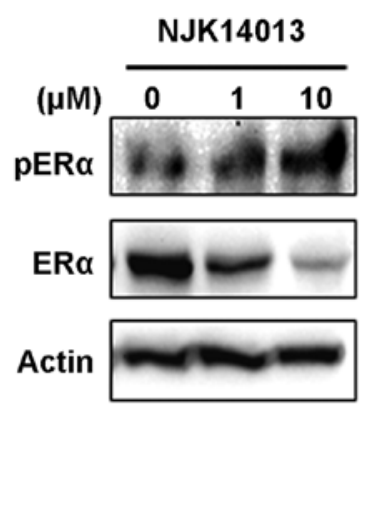

Figure 2. Stimulation of ER transcriptional activity by NJK14013. (A) Assessment of GREB1 mRNA levels by RT-qPCR. Total RNA was prepared from MCF7 cells treated with the indicated concentrations of E2 or NJK14013, and GREB1 mRNA levels were determined by RT-qPCR as described in Materials and methods. Data are presented as means $\pm \mathrm{SD}\left({ }^{*} \mathrm{p}<0.05\right.$ and ${ }^{* *} \mathrm{p}<0.01$ versus mock-treated). (B) Induction of ER phosphorylation by NJK14013. MCF7 cells were treated with the indicated concentrations of NJK14013 for $24 \mathrm{~h}$. After lysis, samples were analyzed by immunoblotting using anti-phospho-ER $\alpha$ (Ser104/106), anti-ER $\alpha$ and anti- $\beta$-actin antibodies.

activity with a median effective concentration $\left(\mathrm{EC}_{50}\right)$ value of $46.3 \pm 12 \mathrm{nM}$ (Fig. 1C). To determine whether this activity was specific for ER-mediated transcription, we analyzed the effect of NJK14013 on AR-mediated transcription using MMTV promoter- and PSA promoter-driven luciferase reporters. Unlike ER-driven transcription, AR-driven PSA promoterand MMTV enhancer/promoter-reporter activity in LNCaP cells were not activated by NJK14013 (Fig. 1D). These results suggest that NJK14013 differentially interacts with and regulates the ER and AR, although the molecular basis for these differential effects is not clear.

To further confirm the agonistic activity of NJK14013 on ER transcriptional activity, we analyzed the effects of NJK14013 on the transcription of GREB1, an ER-responsive gene. As depicted in Fig. 2A, treatment with E2 or NJK14013 induced a significant increase in GREB1 mRNA. Since interaction with estrogen causes the ER to undergo phosphorylation, which results in ER dimerization and nuclear translocation, we examined whether NJK14013 affected the phosphorylation status of the ER. As shown in Fig. 2B, cells treated with NJK14013 showed increased levels of phosphorylated ER (Ser104/106) and decreased levels of total ER protein.

These results suggest that NJK14013 may interact with ER and modulate its activity. To investigate the binding modes of NJK14013 in the active site of the ER ligandbinding domain(LBD) active site, we performed molecular docking studies based on the human ER $\alpha$ crystal structure (PDB code: 2QXS). As expected, the compound fit well into the active site, with an estimated free energy of binding of $-8.08 \mathrm{kcal} / \mathrm{mol}$. One of the phenols in NJK14013 interacted with Glu353 of the protein, whereas the other phenol formed a hydrogen bond with His524. In addition, an isopentyl tether occupied the hydrophobic region of the pocket. The key hydrogen bonding interaction and overall binding mode with $\mathrm{ER} \alpha$ were similar to those of raloxifene (Fig. 3).

NJK14013 suppresses proliferation of tumor cells in an ER-independent manner. Next, we tested the effect of

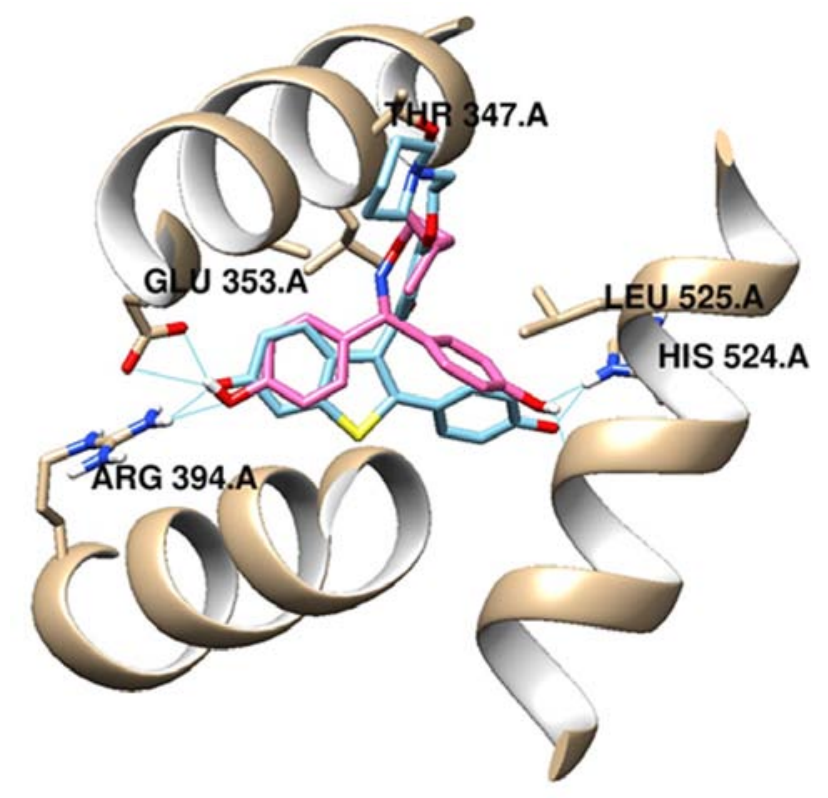

Figure 3. Molecular modeling of NJK14013 interaction with ER $\alpha$. Docking of NJK14013 (pink) and raloxifene (blue) into ER $\alpha$ (PDB code: 2QXS) was performed using Autodock 4.2 and the results were visualized using Chimera 1.10.

NJK14013 on the proliferation of various cancer cell lines. To our surprise, treatment with $10 \mu \mathrm{M}$ NJK14013 clearly suppressed the proliferation of MCF7 cells; in contrast, the same concentration of E2 did not significantly affect MCF7 cell proliferation (Fig. 4A). NJK14013 also suppressed the proliferation of Ishikawa endometrial cancer cells, MDA-MB-231 breast cancer cells, and A549 lung adenocarcinoma cells, indicating that it is capable of suppressing diverse types of tumor cells (Fig. 4B-D). Consistent with MTT assay results, the protein level of proliferating cell nuclear antigen (PCNA), a well-known proliferation marker, was significantly decreased by NJK14013 treatment in MCF7 cells (Fig. 4E). 
A

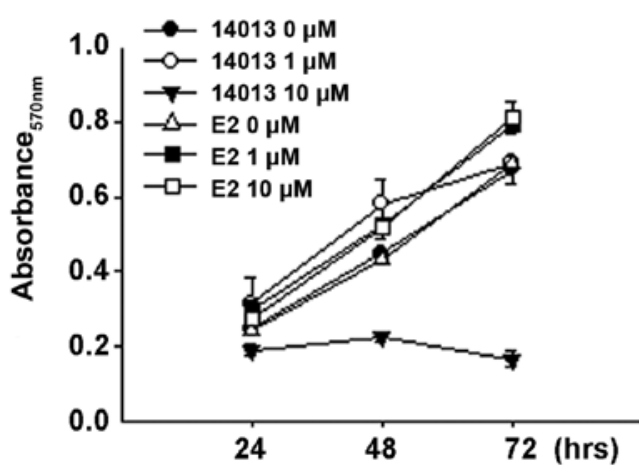

C

MDA-MB-231

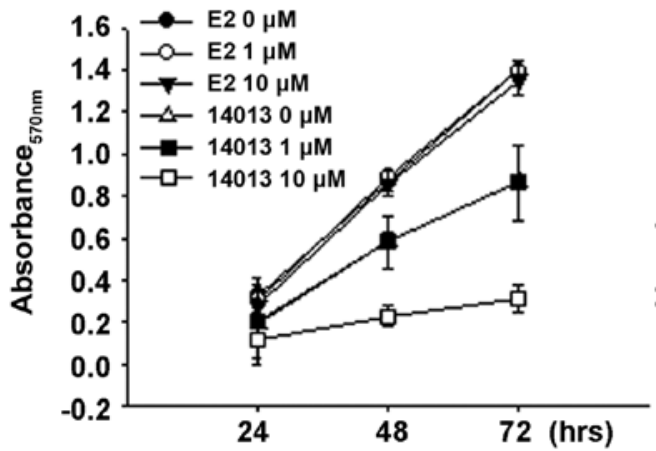

B

Ishikawa

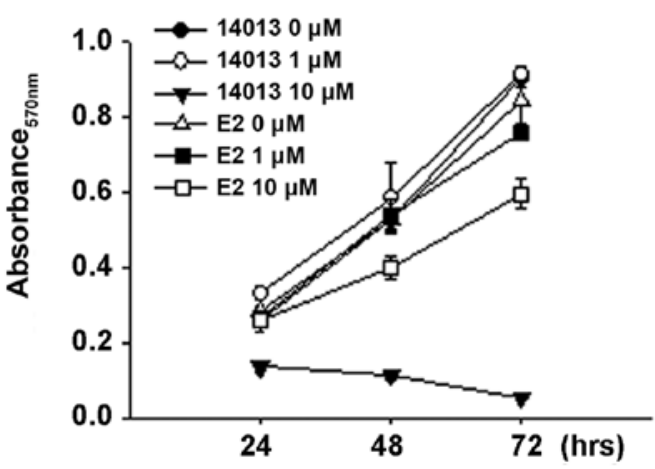

D

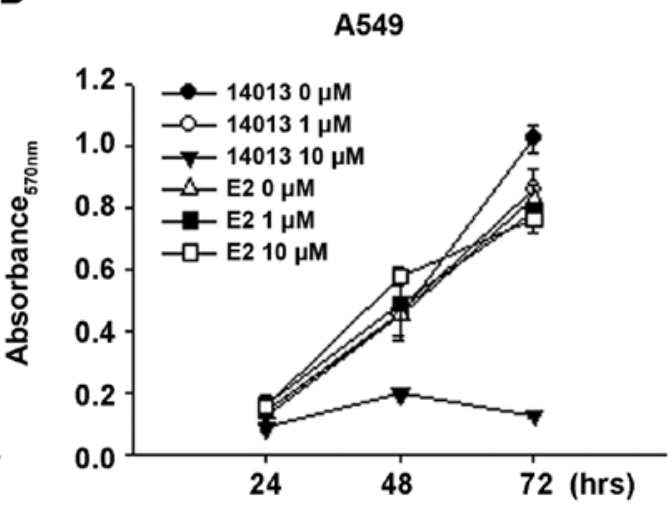

E

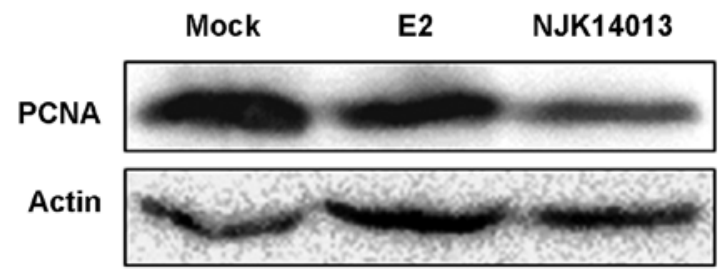

Figure 4. ER-independent suppression of tumor-cell proliferation by NJK14013. (A-D) MCF7 (A), Ishikawa (B), MDA-MB-231 (C) and A549 (D) cells were seeded onto 96-well tissue culture plates $\left(1 \times 10^{4}\right.$ cells/well). After incubating for $18 \mathrm{~h}$, cells were treated with increasing concentrations of E2 or NJK14013 (14013) for 24,48 or $72 \mathrm{~h}$. Proliferation of cells was determined by MTT assays. Data are presented as means \pm SD. (E) MCF7 cells were treated with $10 \mu \mathrm{M}$ E2 or NJK14013 for $24 \mathrm{~h}$ and then analyzed by immunoblotting using anti-PCNA and anti- $\beta$-actin antibodies.

A

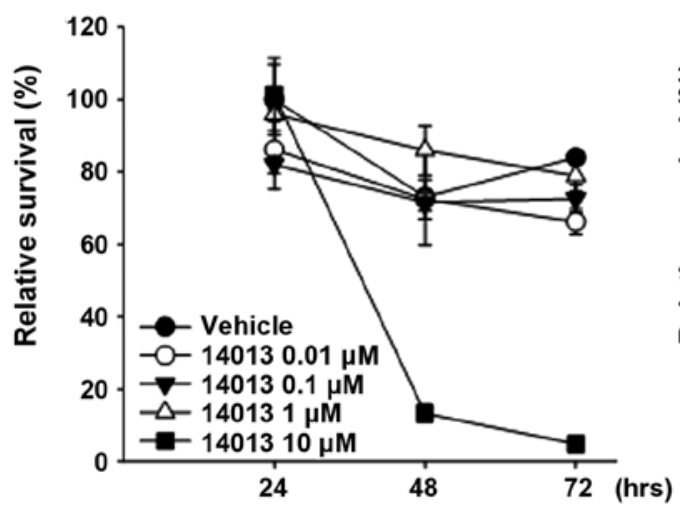

B

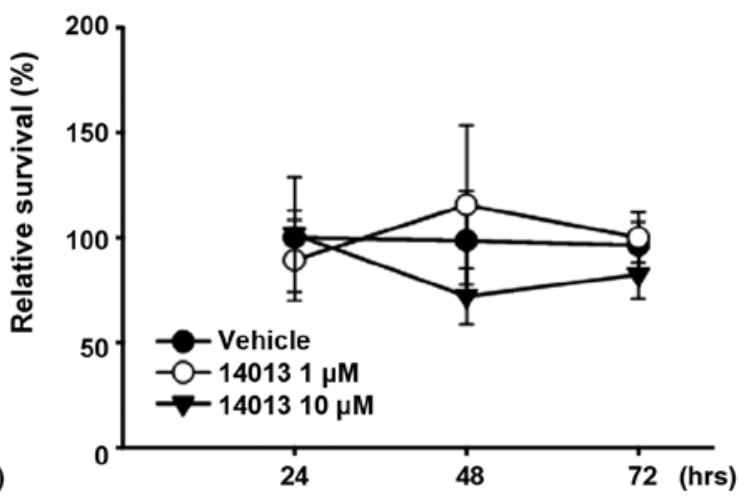

Figure 5. Induction of apoptotic death of tumor cells by NJK14013. (A and B) Induction of cell death by NJK14013 (14013) in Ishikawa cells. Ishikawa (A) and HUVEC (B) cells were seeded onto 96 -well plates $\left(4 \times 10^{4}\right.$ cells/well). After incubation for $24 \mathrm{~h}$, cells were treated with vehicle or the indicated concentrations of NJK14013 for 24, 48 or $72 \mathrm{~h}$. Cell viability was determined by MTT assay as described in Materials and methods. 

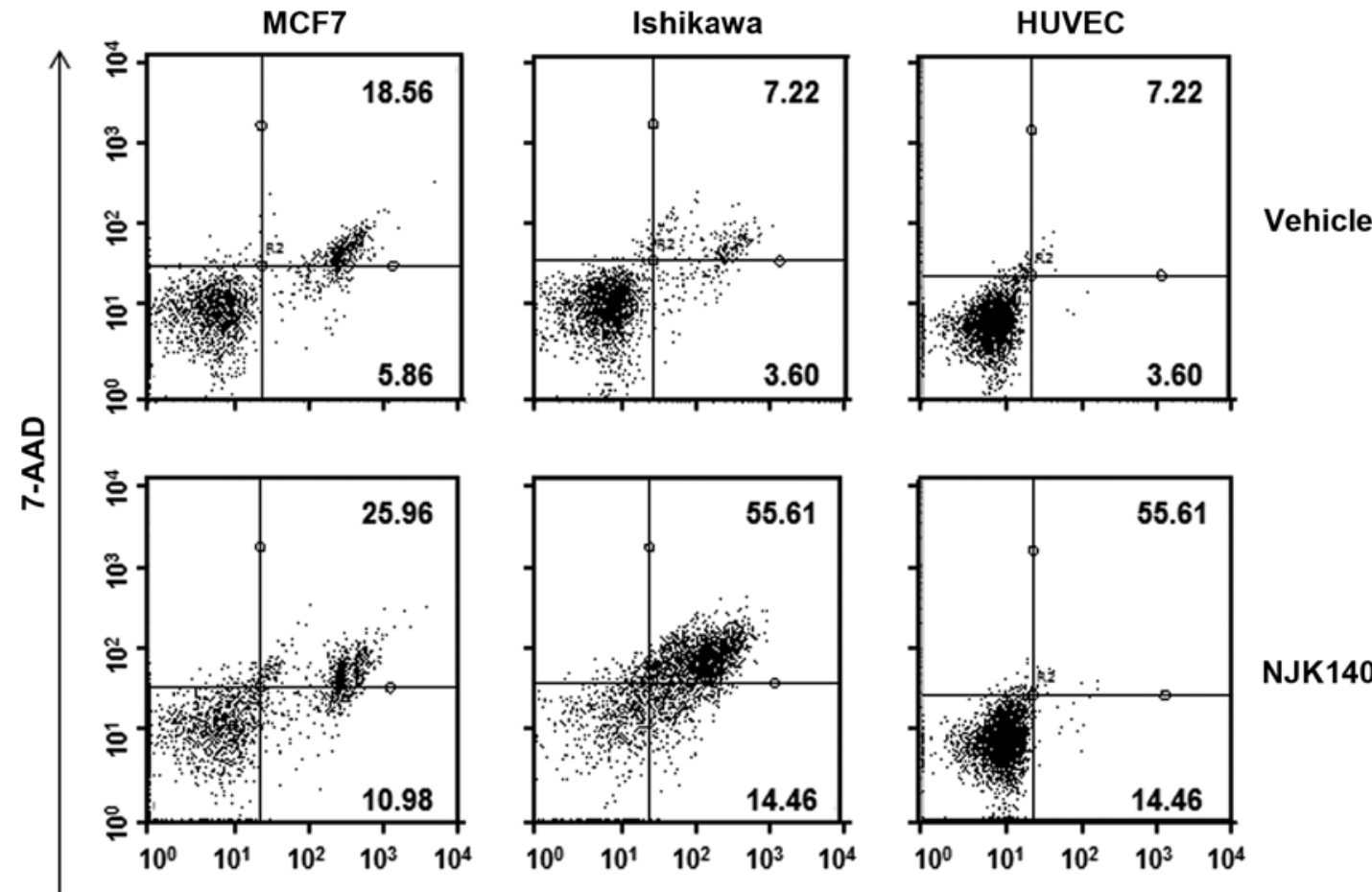

NJK14013

Annexin V-PE

Figure 6. Induction of apoptotic death in cancer cells by NJK14013. MCF7, Ishikawa and HUVEC cells were treated with vehicle or NJK14013 (10 $\mu$ M) for $48 \mathrm{~h}$. Apoptotic cell death was assessed by Annexin V/7-AAD staining and analyzed by flow cytometry.

Considering that MDA-MB-231 is an ER-negative breast cancer cell line, these results imply that the tumor-suppressive effect of NJK14013 is not ER-dependent.

NJK14013 induces apoptotic death of tumor cells. Finally, we tested whether NJK14013 induced tumor cell death in addition to suppressing tumor cell proliferation using Ishikawa cells. Unlike E2, treatment with NJK14013 $(10 \mu \mathrm{M})$ resulted in 87 and 95\% cell death after 48 and 73 h, respectively (Fig. 5A). In stark contrast, the same concentrations caused no significant change in the viability of HUVECs within $72 \mathrm{~h}$ after treatment (Fig. 5B).

To examine whether NJK14013 is able to cause apoptotic death of cancer cells, we analyzed MCF7, Ishikawa, and HUVEC cells by Annexin V/7-AAD assays after treatment with NJK14013 for 48 h. As shown in Fig. 6, treatment with NJK14013 caused apoptotic cell death in 25.96 and $55.61 \%$ of MCF7 and Ishikawa cells, respectively. In contrast, NJK14013 treatment did not significantly increase apoptosis of HUVECs, further supporting cell viability data (Fig. 6).

\section{Discussion}

Estrogens and SERMs exert various effects on different types of tumor cells. For instance, tamoxifen displays an ER antagonistic effect in MCF7 cells and suppresses breast cancer cell proliferation, whereas it increases the risk of endometrial cancer. Hormone replacement therapy using estrogen to treat postmenopausal syndrome and osteoporosis has been associated with an increased risk of breast cancer. In this study, we sought to identify biologically active compounds that are capable of stimulating ER activity while suppressing proliferation of various tumor cells. We identified NJK14013 as a novel compound which enhances the transcriptional activity of ER $\alpha$. The agonistic effect of NJK14013 on the ER suggests its possible use for estrogen-deficiency-related conditions, such as osteoporosis. However, the ER agonistic effect in MCF7 also raises concerns that NJK14013 might increase the risk of breast cancer or facilitate the proliferation of cancer cells.

Our results demonstrate that NJK14013 is a novel SERM capable of inducing apoptotic death in various cancer cell types. An ER-agonistic role of NJK14013 in MCF7 cells indicates that NJK14013 may act through a different mechanism than tamoxifen and raloxifene, which exert ER-antagonistic activity in MCF7 cells. The SERM actions of NJK14013 in various other tissues, including bone and endometrium, remain to be determined. Although the mechanism underlying the anticancer effect of NJK14013 is not clear, it does not appear to be dependent on its ER-modulating activity since NJK14013 showed similar effects on ER-negative cancer cells. Interestingly, a recent study identified ospemifene derivatives that were cytotoxic to both MCF7 and MDA-MB-231, despite the fact that ospemifene itself is selective for ER-positive MCF7; moreover, these compounds were not toxic to normal mouse embryonic fibroblasts (25). Thus, it is conceivable that some SERMs may be able to acquire ER-independent, cancer cell-specific cytotoxicity while retaining ER-modulating activity. Elucidating the molecular target and underlying cytotoxicity mechanism of NJK14013 will require further studies.

Collectively, our results suggest the potential use of NJK14013 as a novel SERM for hormone-replacement therapy with reduced risk of carcinogenesis or tumor progression. 
In addition, its tumor-suppressive effects on various cancer cell types at concentrations that do not affect the viability of non-cancer cells (HUVECs) indicate its potential use as an anticancer therapeutic.

\section{Acknowledgements}

This study was supported by Basic Science Research Program through the National Research Foundation of Korea (NRF) funded by the Ministry of Science, ICT \& Future Planning (NRF-2012R1A1A1015130) and in part a grant from Kyung Hee University in 2013 (KHU-20130981).

\section{References}

1. Mirkin S, Archer DF, Pickar JH and Komm BS: Recent advances help understand and improve the safety of menopausal therapies. Menopause 22: 351-360, 2015.

2. Martinkovich S, Shah D, Planey SL and Arnott JA: Selective estrogen receptor modulators: Tissue specificity and clinical utility. Clin Interv Aging 9: 1437-1452, 2014.

3. Chedraui P, Pérez-López FR, Hidalgo L, Villacreses D Domínguez A, Escobar GS, Genazzani AR and Simoncini T; Research Group for the Omega Women's Health Project: Evaluation of the presence and severity of menopausal symptoms among postmenopausal women screened for the metabolic syndrome. Gynecol Endocrinol: Oct 27, 2014 (Epub ahead of print) 1-7, 2014

4. Ismailoğlu O, Oral B, Gorgulu A, Sutcu R and Demir N Neuroprotective effects of tamoxifen on experimental spinal cord injury in rats. J Clin Neurosci 17: 1306-1310, 2010.

5. Ishihara Y, Itoh K, Ishida A and Yamazaki T: Selective estrogenreceptor modulators suppress microglial activation and neuronal cell death via an estrogen receptor-dependent pathway. J Steroid Biochem Mol Biol 145: 85-93, 2015.

6. Pietras RJ: Biologic basis of sequential and combination therapies for hormone-responsive breast cancer. Oncologist 11: 704-717, 2006.

7. Kuss JT, Muss HB, Hoen H and Case LD: Tamoxifen as initial endocrine therapy for metastatic breast cancer: Long term follow-up of two Piedmont Oncology Association (POA) trials. Breast Cancer Res Treat 42: 265-274, 1997.

8. Vogel CL, Johnston MA, Capers C and Braccia D: Toremifene for breast cancer: A review of 20 years of data. Clin Breast Cancer 14: 1-9, 2014.

9. Viedma-Rodríguez R, Baiza-Gutman L, Salamanca-Gómez F, Diaz-Zaragoza M, Martínez-Hernández G, Ruiz EsparzaGarrido R, Velázquez-Flores MA and Arenas-Aranda D: Mechanisms associated with resistance to tamoxifen in estrogen receptor-positive breast cancer (review). Oncol Rep 32: 3-15, 2014.

10. Kurebayashi J: Endocrine-resistant breast cancer: Underlying mechanisms and strategies for overcoming resistance. Breas Cancer 10: 112-119, 2003

11. Decensi A, Maisonneuve P, Rotmensz N, Bettega D, Costa A, Sacchini V, Salvioni A, Travaglini R, Oliviero P, D'Aiuto G, et al; Italian Tamoxifen Study Group: Effect of tamoxifen on venous thromboembolic events in a breast cancer prevention trial. Circulation 111: 650-656, 2005.
12. Bonneterre J, Thürlimann B, Robertson JF, Krzakowski M, Mauriac L, Koralewski P, Vergote I, Webster A, Steinberg M and von Euler M: Anastrozole versus tamoxifen as first-line therapy for advanced breast cancer in 668 postmenopausal women: Results of the Tamoxifen or Arimidex Randomized Group Efficacy and Tolerability study. J Clin Oncol 18: 3748-3757, 2000.

13. Nagy E, Gajjar KB, Patel II, Taylor S, Martin-Hirsch PL, Stringfellow HF, Martin FL and Phillips DH: MGMT promoter hypermethylation and K-RAS, PTEN and TP53 mutations in tamoxifen-exposed and non-exposed endometrial cancer cases. Br J Cancer 110: 2874-2880, 2014.

14. Avis NE, Crawford SL and McKinlay SM: Psychosocial, behavioral, and health factors related to menopause symptomatology. Womens Health 3: 103-120, 1997.

15. Buster JE: Transdermal menopausal hormone therapy: Delivery through skin changes the rules. Expert Opin Pharmacother 11: 1489-1499, 2010

16. Jordan VC: The new biology of estrogen-induced apoptosis applied to treat and prevent breast cancer. Endocr Relat Cancer 22: R1-R31, 2015.

17. Kelly JP, Kaufman DW, Rosenberg L, Kelley K, Cooper SG and Mitchell AA: Use of postmenopausal hormone therapy since the Women's Health Initiative findings. Pharmacoepidemiol Drug Saf 14: 837-842, 2005 .

18. Rossouw JE, Anderson GL, Prentice RL, LaCroix AZ, Kooperberg C, Stefanick ML, Jackson RD, Beresford SA, Howard BV, Johnson KC, et al; Writing Group for the Women's Health Initiative Investigators: Risks and benefits of estrogen plus progestin in healthy postmenopausal women: Principal results From the Women's Health Initiative randomized controlled trial. JAMA 288: 321-333, 2002.

19. Chlebowski RT, Hendrix SL, Langer RD, Stefanick ML, Gass M, Lane D, Rodabough RJ, Gilligan MA, Cyr MG, Thomson CA, et al; WHI Investigators: Influence of estrogen plus progestin on breast cancer and mammography in healthy postmenopausal women: The Women's Health Initiative Randomized Trial. JAMA 289: 3243-3253, 2003

20. Craig Jordan V, McDaniel R, Agboke F and Maximov PY: The evolution of nonsteroidal antiestrogens to become selective estrogen receptor modulators. Steroids 90: 3-12, 2014

21. DeGregorio MW, Zerbe RL and Wurz GT: Ospemifene: A firstin-class, non-hormonal selective estrogen receptor modulator approved for the treatment of dyspareunia associated with vulvar and vaginal atrophy. Steroids 90: 82-93, 2014.

22. Kim HI, Quan FS, Kim JE, Lee NR, Kim HJ, Jo SJ, Lee CM, Jang DS and Inn KS: Inhibition of estrogen signaling through depletion of estrogen receptor alpha by ursolic acid and betulinic acid from Prunella vulgaris var. lilacina. Biochem Biophys Res Commun 451: 282-287, 2014.

23. Morris GM, Huey R, Lindstrom W, Sanner MF, Belew RK, Goodsell DS and Olson AJ: AutoDock4 and AutoDockTools4: Automated docking with selective receptor flexibility. J Comput Chem 30: 2785-2791, 2009.

24. Pettersen EF, Goddard TD, Huang CC, Couch GS, Greenblatt DM, Meng EC and Ferrin TE: UCSF Chimera - a visualization system for exploratory research and analysis. J Comput Chem 25: 1605-1612, 2004

25. Kaur G, Mahajan MP, Pandey MK, Singh P, Ramisetti SR and Sharma AK: Design, synthesis and evaluation of Ospemifene analogs as anti-breast cancer agents. Eur J Med Chem 86: 211-218, 2014. 